\title{
Spójność polskiego systemu wspierania umiędzynarodowienia działalności małych i średnich przedsiębiorstw w latach 2007-2013 - ocena i rekomendacje na nową perspektywę finansową 2014-2020
}

\author{
Justyna Kulawik-Dutkowska*
}

\begin{abstract}
Celem artykutu jest opisanie systemu wspierania umiędzynarodowienia (internacjonalizacji) działalności małych $i$ średnich przedsiębiorstw, ocena jego silnych $i$ stabych stron oraz wypracowanie rekomendacji na przyszłość, w szczególności w kontekście nowej wieloletniej perspektywy finansowej na lata 2014-2020. System wspierania umiędzynarodowienia MŚP w Polsce jest wysoce ztożony. Obejmuje instrumenty wsparcia bezpośredniego, adresowane wprost do przedsiębiorców i zarządzane na szczeblu unijnym, krajowym i regionalnym, zwlaszcza $w$ postaci funduszy strukturalnych. Kolejna grupq sq instrumenty wsparcia pośredniego w postaci ustug świadczonych przedsiębiorcom przez instytucje otoczenia biznesu, a także wsparcie ze środków publicznych oferowane tym instytucjom. Można też wyróżnić instrumenty wspierające dziatalność polskich przedsiębiorców za granica oraz instrumenty wspierajace dziatalność innowacyjna przedsiębiorców, przyczyniające się do poprawy ich konkurencyjności na rynkach zagranicznych. $W$ artykule podjęto próbę oceny funkcjonowania tego systemu, przede wszystkim pod kątem jego spójności, bazująca głównie na analizie dokumentów strategicznych i programowych, przegladzie instrumentów wsparcia oraz analizie dziatalności instytucji zaangażowanych we wspieranie umiędzynarodowienia MŚP. Na podstawie dokonanej oceny sformutowano rekomendacje $w$ zakresie poprawy funkcjonowania systemu, mogące stanowić punkt wyjścia do dyskusji nad wprowadzeniem ewentualnych zmian w latach 2014-2020.
\end{abstract}

Słowa kluczowe: umiędzynarodowienie, internacjonalizacja, MŚP, system wsparcia, fundusze strukturalne.

Nadesłany: 15.06.2014 | Zaakceptowany do druku: 05.09.2014

\section{Coherence of the Polish system of support of SMEs' internationalisation - evaluation and recommendations for the new financial perspective 2014-2020}

The aim of this article is to describe the system of support of SMEs' internationalization, assess its strengths and weaknesses and develop recommendations for the future, in particular with regard to the new multiannual financial perspective 2014 - 2020. System of support of SMEs' internationalization is very complex, it encloses direct support instruments addressed to entrepreneurs implemented at EU, national and regional level, especially through Structural Funds, indirect support instruments, such as services provided by business support organisations and public support addressed to these institutions. Measures supporting directly Polish entrepreneurs' business activities abroad and those supporting development of innovative activities of companies contributing to improvement of their competitiveness at the international markets

\footnotetext{
Mgr Justyna Kulawik-Dutkowska - Uniwersytet Warszawski, Wydział Zarządzania.

Adres do korespondencji: Uniwersytet Warszawski, Wydział Zarządzania UW, ul. Szturmowa 1/3, 02-678 Warszawa; e-mail: justynakulawik@yahoo.com.
} 
could also be mentioned. Author will attempt to assess the functioning of the system, in particular with regard to its coherence. It will be mainly based on analysis of the strategic and programming documents, review of instruments of support and analysis of activities of institutions engaged in supporting the SMEs' internationalization. Based on the assessment, recommendations regarding improvement of the system will be issued which could provide a starting point for the discussion on a possibility to introduce changes in 2014-2020 perspective.

Keywords: internationalisation, SME, system of support, Structural Funds.

Submitted: 15.06.2014 | Accepted: 05.09.2014

JEL: L53

\section{Wprowadzenie}

W ostatnich latach w związku z otwarciem polskiej gospodarki, integracją z Unią Europejską i postępującym zjawiskiem globalizacji zjawisko internacjonalizacji (umiędzynarodowienia) odgrywa coraz większą rolę $\mathrm{w}$ funkcjonowaniu polskich przedsiębiorstw. W literaturze przedmiotu brakuje jednej powszechnie stosowanej definicji internacjonalizacji. Pojęcie internacjonalizacji można więc rozumieć jako międzynarodowe powiązania między jednostkami (w tym przedsiębiorstwami) przybierające różne formy, np. przemieszczania dóbr materialnych czy przepływu środków finansowych (Sporek, 2000). Z kolei J. Rymarczyk definiuje internacjonalizację jako „każdy rodzaj działalności gospodarczej podejmowanej przez przedsiębiorstwo za granicą. Jest to ujęcie szersze w odróżnieniu od tych, które uzależniają stosowanie pojęcia internacjonalizacji od określonego stopnia intensywności i zaangażowania przedsiębiorstwa za granicą" (Rymarczyk, 2004). W podobny sposób można definiować to pojęcie jako „ekspansję operacji przedsiębiorstwa na rynki zagraniczne" (Korsakienè i Tvaronavičienè, 2012). Przyjmuje się, że zjawisko internacjonalizacji można interpretować na trzy sposoby (Rymarczyk, 2004):

- jako proces polegający na rozwijaniu się od przedsiębiorstwa narodowego poprzez międzynarodowe do globalnego;

- statycznie poprzez m.in. zastosowanie określonych wskaźników w celu zbadania stopnia umiędzynarodowienia przedsiębiorstwa;

- w sposób uzależniony od postępowania (behawiorystyczny), tj. badający sposób postępowania (strategii) kierownictwa międzynarodowego przedsiębiorstwa.
Jednocześnie niektórzy autorzy wskazują na handel zagraniczny i bezpośrednie inwestycje zagraniczne (BIZ) jako najważniejsze przejawy internacjonalizacji gospodarki, a ponadto wyróżniają internacjonalizację czynną, tj. eksport dóbr i usług oraz eksport kapitału (wypływ BIZ za granicę), oraz internacjonalizację bierną $\mathrm{w}$ postaci importu dóbr i usług oraz napływu BIZ do danego kraju (Gorynia, 2002).

W literaturze w kontekście internacjonalizacji zwraca się także uwagę na MŚP jako na szczególne podmioty odgrywające istotną rolę $\mathrm{w}$ tworzeniu wzrostu gospodarczego i w przemianach ekonomicznych, a w warunkach globalizacji konfrontowane z międzynarodową konkurencją i zmuszane do rywalizacji na rynkach zagranicznych (Korsakienè i Tvaronavičienè, 2012) ${ }^{1}$. Rozważane są także sposoby realizacji rodzajów polityki publicznej mających na celu zwiększenia konkurencyjności gospodarki, m.in. w kontekście internacjonalizacji (Gorynia, 2002).

W latach 2007-2013 przeznaczono w Polsce znaczne środki finansowe na działania mające na celu zwiększenie umiędzynarodowienia polskich przedsiębiorstw, zwłaszcza tych z sektora MŚP, przy czym zdecydowana większość instrumentów wsparcia miała za zadanie przede wszystkim pobudzanie ich działalności eksportowej. Najważniejsza część pozostających w tym okresie do dyspozycji środków finansowanych pochodziła z funduszy strukturalnych, przede wszystkim w ramach Programu Operacyjnego Innowacyjna Gospodarka i Regionalnych Programów Operacyjnych. Ponadto angażowane były środki budżetu państwa, m.in. przeznaczane na utrzymanie placówek dyplomatycznych i Wydziałów Ekonomiczno-Handlowych (później Wydziałów Promocji Handlu i Inwestycji) 
przy ambasadach, pomoc de minimis czy też rządowe programy finansowania eksportu.

W system wsparcia internacjonalizacji przedsiębiorstw zaangażowana jest znacząca liczba instytucji na szczeblu unijnym, krajowym i regionalnym. W niniejszym artykule podjęto próbę odpowiedzi na pytanie: czy ten niezwykle skomplikowany i złożony system instrumentów wsparcia, przeznaczonych przede wszystkim na zwiększenie eksportu, jest spójny. Podjęto także próbę wypracowania rekomendacji w zakresie instrumentów wsparcia w nowej perspektywie budżetowej na lata 2014-2020.

\section{Kształtowanie się polityki wspierania umiędzynarodowienia (internacjonalizacji) przedsiębiorstw z sektora MŚP na lata $2007-2013$}

W 2009 r. Komisja Europejska zleciła przeprowadzenie badania na temat poziomu internacjonalizacji europejskich przedsiębiorstw (EIM Business \& Policy Research, 2010). W jego ramach przebadano 9,480 firm z sektora MŚP w 33 europejskich krajach, analizując wszystkie działania, w których przedsiębiorstwo wchodzi w znaczące relacje biznesowe $\mathrm{z}$ zagranicznymi partnerami, tj. eksport, import, bezpośrednie inwestycje zagraniczne, międzynarodowe podwykonawstwo oraz zagraniczną współpracę technologiczną. Badanie potwierdziło m.in., że większość MŚP prowadzących działalność eksportową wykonywało ją głównie na rynek wewnętrzny UE. Oprócz określenia stanu internacjonalizacji sektora MŚP ustalono prawidłowości, uzasadniające potrzebę wspierania internacjonalizacji przedsiębiorstw:

1) umiędzynarodowione MŚP tworzą więcej miejsc pracy: aktywne międzynarodowo MSP odnotowały 7\% wzrost zatrudnienia, w przeciwieństwie do $1 \%$ wzrostu w MŚP niepodejmujących żadnych działań międzynarodowych;

2) umiędzynarodowione MŚP są bardziej innowacyjne: $26 \%$ aktywnych międzynarodowo MŚP wprowadziło produkty lub usługi będące nowością na tle swojego sektora w swoim kraju, podczas gdy dla innych MŚP ten wskaźnik wyniósł jedynie $8 \%$;

3) publiczne wsparcie pozostaje przeważnie niezauważalne dla jego adresatów; jedy- nie $16 \%$ MŚP ma świadomość istnienia publicznych programów wspierania internacjonalizacji, a jedynie niewielka liczba MŚP korzysta z publicznego wsparcia.

$Z$ reguły MŚP rozpoczynaja aktywność międzynarodową przez działania importowe - MŚP aktywne zarówno w imporcie, jak i eksporcie dwa razy częściej rozpoczynały swoją działalność jako importerzy (39 do 18\%).

W „Koncepcji horyzontalnej polityki przemysłowej w Polsce" z 2007 r. jako jeden z obszarów planowanych działań wymienia się rynki zbytu. W dokumencie przewidziano, iż celem planowanego wsparcia ma być „wspieranie kontaktów handlowych przedsiębiorców z partnerami zagranicznymi, w tym doradztwo i szkolenia w zakresie promocji sprzedaży za granicę, badania rynków zagranicznych, udział w imprezach targowo-wystawienniczych, budowa i rozwój internetowego systemu obsługi przedsiębiorców poszukujących partnerów handlowych oraz możliwości podjęcia inwestycji na terenie Polski, wsparcie inwestorów za pomocą sieci centrów obsługi" (Koncepcja, 2007, s. 18) Ponadto wskazano na istotną rolę ubezpieczeń średnio- i długoterminowych kredytów eksportowych oraz konieczność promowania wizerunku Polski i polskich produktów za granicą.

W Programie Operacyjnym Innowacyjna Gospodarka 2007-2013 w zakresie szeroko rozumianej promocji gospodarczej Polski stwierdzono, że „efekty dotychczas podejmowanych działań promocyjnych oceniane są jako niewystarczające w stosunku do istniejących potrzeb. Brak jest na przykład jednolitego, systemowego wsparcia dla eksporterów i inwestorów o zasięgu krajowym" (Program Operacyjny Innowacyjna Gospodarka, 2013, s. 32). Według autorów Programu mało atrakcyjny wizerunek Polski przekładał się na niewystarczający popyt na eksportowane produkty, stwierdzono też, że poziom wydatków publicznych na promocję eksportu w Polsce był niemalże dwunastokrotnie niższy niż poziom takich wydatków w krajach UE-15.

W 2009 r. Polska Agencja Rozwoju Przedsiębiorczości zleciła przeprowadzenie badania dotyczącego planów i potrzeb przedsiębiorców sektora MŚP w zakresie rozwoju eksportu i powiązań z zagranicznymi rynkami i partnerami handlowymi, w kontek- 
ście uruchomienia działania 6.1 PO IG „Paszport do eksportu” (Policy \&Action Group Uniconsult Sp. z o.o., 2009). Z badania wyłonił się zróżnicowany obraz polskich eksporterów: zidentyfikowano znaczące różnice odnośnie do okresu prowadzenia działalności eksportowej, ale także wielkości i stopnia wyspecjalizowania w eksporcie, co wpływało zarówno na skalę podejmowanych działań, jak i odczuwanie przez firmy barier i zapotrzebowania na określone instrumenty wsparcia. Ustalono, że największy udział w eksporcie mają firmy duże i średnie, przy czym coraz większą rolę odgrywały przedsiębiorstwa z kapitałem zagranicznym. Natomiast udział sektora MSP miał tendencję malejącą, co dotyczyło przede wszystkim mikroprzedsiębiorstw. Badanie przyniosło interesujace wnioski w zakresie oczekiwań przedsiębiorców odnośnie do projektowanych instrumentów wsparcia, a mianowicie większość badanych oczekiwała „konkretnych, najczęściej finansowych form pomocy prowadzących wprost do namacalnych/ rzeczywistych efektów" (Policy \&Action Group Uniconsult Sp. z o.o., 2009, s. 120). $\mathrm{Z}$ kolei usługi doradcze, w zakresie tworzenia planów rozwoju eksportu, nie cieszyły się znaczącym zainteresowaniem, poza ewentualnie doradztwem w zakresie pozyskiwania partnerów biznesowych i kapitału.

Przy założeniu, iż rządzący prowadzą politykę gospodarczą opartą na faktach (evidence based policy), można stwierdzić, że instrumenty wspierania internacjonalizacji przedsiębiorstw były kształtowane w opisanym powyżej kontekście społecznoekonomicznym. Podstawy polskiego systemu wsparcia w latach 2007-2013 zostały zdefiniowane jeszcze przed rozpoczęciem wdrażania wieloletniej perspektywy finansowej, tj. podczas tworzenia dokumentów programowych dla funduszy strukturalnych, jednakże szczegółowe zasady udzielania wsparcia były określane na późniejszym etapie, przede wszystkim w aktach wykonawczych (rozporządzeniach) oraz różnego rodzaju regulaminach, wytycznych i opisach kryteriów dotyczących poszczególnych instrumentów. Należy mieć także na uwadze fakt, że dokumenty programowe były uchwalane jeszcze przed wybuchem światowego kryzysu gospodarczego, a wydaje się, że to zjawisko stanowiło dodatkowa motywację dla planowej realizacji działań wspierających przedsiębiorców. Podsumo- wując, można stwierdzić, że dokumenty strategiczne, programowe i wykonawcze w odniesieniu do perspektywy budżetowej 2007-2013 miały spójny charakter w zakresie identyfikacji potrzeb przedsiębiorców, jednakże przewidywały wsparcie o rozdrobnionym charakterze ze względu na dużą liczbę instrumentów i zarządzających nimi instytucji.

\section{System wspierania internacjonalizacji MŚP w latach 2007-2013}

Do instrumentów wsparcia procesu internacjonalizacji polskich firm $w$ tym okresie należały m.in. dotacje bezzwrotne z funduszy strukturalnych, dofinansowanie wydawnictw, certyfikatów bądź atestów niezbędnych dla działalności eksportowej oraz udziału przedsiębiorców w targach i wystawach krajowych i zagranicznych, a także kredyty i gwarancje rządowe oraz ubezpieczenia kredytów eksportowych.

Zwiększeniu umiędzynarodowienia polskiej gospodarki poświęcono w całości Priorytet VI Programu Operacyjnego Innowacyjna Gospodarka, pt. „Polska gospodarka na rynku międzynarodowym”. W ramach priorytetu wspierane były „działania polegające na silniejszym powiązaniu gospodarki polskiej z gospodarką międzynarodowa poprzez przedstawienie Polski jako atrakcyjnego partnera na rynku międzynarodowym, a zarazem atrakcyjnego miejsca do lokowania inwestycji" (Szczegółowy Opis Priorytetów PO IG, 2014, s. 134). Wsparcie adresowane było albo bezpośrednio do przedsiębiorców (działanie 6.1 Paszport do eksportu oraz poddziałanie 6.5.2 Wsparcie udziatu przedsiębiorców w programach promocji), albo przeznaczone pośrednio na ich rzecz wtedy, gdy beneficjentami działań były instytucje otoczenia biznesu, świadczące następnie usługi na rzecz przedsiębiorców (poddziałanie 6.2.1 Wsparcie dla sieci centrów obstugi inwestorów $i$ eksporterów oraz poddziałanie 6.5.1 Promocja gospodarki na rynkach międzynarodowych). W ramach priorytetu przewidziano także dwa instrumenty wspierające turystykę, jednakże nie będą one omawiane w niniejszym opracowaniu ze względu na ich odmienną tematykę. Działania związane z promocją gospodarczą oraz promocją eksportu przewidziano także w Regionalnych Programach Operacyjnych. 


\subsection{Instrumenty bezpośredniego wspierania przedsiębiorstw}

\subsubsection{Dziatanie 6.1 PO IG Paszport do eksportu}

Działanie to było adresowane do przedsiębiorców z sektora MŚP planujących podjęcie działalności eksportowej lub do początkujących eksporterów i miało na celu zwiększenie wolumenu polskiego eksportu oraz liczby przedsiębiorców prowadzących działalność na rynkach zagranicznych. Jednocześnie, dzięki dofinansowaniu udziału polskich przedsiębiorców w targach i misjach gospodarczych miało przyczyniać się do promocji polskiej gospodarki za granicą. Specyfiką tego działania było udzielanie dofinansowania dużej liczbie projektów o stosunkowo niewielkiej wartości i znaczacy udział w konkursach mikro- i małych firm. Na początku dofinansowane projekty miały składać się z dwóch etapów, tj. sporządzenia planu rozwoju eksportu (etap I) oraz jego wdrożenia (etap II), co obejmowało m.in. udział w zagranicznych imprezach targowo-wystawienniczych, misjach gospodarczych za granica, pozyskanie dokumentów niezbednych do wprowadzenia produktu lub usługi na wybrane rynki docelowe czy pomoc doradczą w opracowaniu strategii finansowania lub kreowania wizerunku. W późniejszych konkursach zrezygnowano $\mathrm{z}$ wymogu dwuetapowości.

Jak widać, przy określaniu szczegółowych zasad realizacji konkursów w ramach tego działania nie uwzględniono niechęci przedsiębiorców do planowej realizacji działań eksportowych w oparciu o przemyślaną strategię, o czym pisano we wspomnianym wcześniej badaniu (Policy \&Action Group Uniconsult Sp. Z o.o., 2009). Ciekawe obserwacje $\mathrm{z}$ tym związane przedstawione zostały $\mathrm{w}$ ewaluacji przeprowadzonej na zlecenie Ministerstwa Rozwoju Regionalnego (PAG Uniconsult, 2011). Niektórzy badani kwestionowali podział zadania na dwa obowiązkowe etapy, argumentując to m.in. sporządzaniem planów rozwoju eksportu przez firmy doradcze według jednego wzorca, co w rzeczywistości znacznie obniżało ich jakość. $\mathrm{Z}$ drugiej strony wskazywano na małą elastyczność w procesie realizacji projektu, gdyż ze względu na upływ czasu pomiędzy sporządzeniem planu a złożeniem wniosku o dofinansowanie jego wdrożenia następo- wała zmiana okoliczności, skutkująca np. dezaktualizacją zaplanowanych, konkretnych imprez targowych ze względu na dynamiczne zmiany otoczenia gospodarczego.

\subsubsection{Poddziatanie 6.5.2 PO IG}

Pomoc finansowa $\mathrm{w}$ formie pomocy $d e$ minimis była udzielana przedsiębiorcom na udział w branżowych programach promocji, stanowiących kompleksowe programy promocji konkretnej branży lub grupy produktowej, co miało kreować polskie specjalności eksportowe. Przedsiębiorcy mogli także uczestniczyć $\mathrm{w}$ programach promocji o charakterze ogólnym, tj. promujących Polskę i polską gospodarkę podczas imprez promocyjnych w kraju i za granicą.

Specyfika tego działania polegała na ograniczonej swobodzie samodzielnego kształtowania planów eksportowych przez przedsiębiorców. Wynikało to $\mathrm{z}$ faktu, że przedsiębiorcy mogli brać udział w z góry określonych przedsięwzięciach. Ponadto, w przypadku programów branżowych, oferta kierowana była jedynie do przedstawicieli danej branży wybranej przez administrację, np. branży produkcji sprzętu medycznego i aparatury pomiarowej. Jeżeli zaś chodzi o udział przedsiębiorców w programach promocji o charakterze ogólnym, to mógt on obejmować jedynie udział w określonych imprezach w konkretnych krajach, uznanych przez Ministerstwo Gospodarki za perspektywiczne. Do krajów tych należały państwa spoza Europejskiego Jednolitego Rynku, tj. Algieria, Brazylia, Kanada, Kazachstan, Turcja, Meksyk i Zjednoczone Emiraty Arabskie.

Przedsiębiorcy korzystający z tego instrumentu byli w zasadzie zadowoleni, zwracali jednak uwage m.in. na zbyt niski poziom dofinansowania, konieczność zwiększenia możliwości nawiązywania bezpośrednich kontaktów z potencjalnymi partnerami biznesowymi, a w mniejszym stopniu z przedstawicielami administracji, a także na konieczność większego zaangażowania polskich placówek dyplomatycznych oraz szersze informowanie potencjalnych beneficjentów o możliwościach udziału w programie (PAG Uniconsult, wrzesień 2011).

\subsubsection{Regionalne Programy Operacyjne}

W Regionalnych Programach Operacyjnych także przewidziano wsparcie na udział przedsiębiorców w targach, wystawach i misjach gospodarczych. 
I tak przykładowo, tego typu działania pojawiły się w następujących RPO:

$\rightarrow$ RPO Województwa Mazowieckiego: dziatanie 1.7 Promocja gospodarcza, gdzie przewidziano m.in. wsparcie na uczestnictwo przedsiębiorców w targach, imprezach targowo-wystawienniczych w charakterze wystawcy oraz udział w branżowych misjach gospodarczych mających na celu wyszukiwanie i dobór partnerów na rynkach docelowych;

$\rightarrow$ RPO Województwa Dolnośląskiego: Poddziatanie 1.2.C Dotacje dla MŚP $w$ zakresie nawiazywania kontaktów gospodarczych (targi, misje), gdzie dofinansowanie przewidziano m.in. na udział przedsiębiorców w targach i wystawach międzynarodowych oraz międzynarodowych misjach gospodarczych;

$\rightarrow$ RPO Województwa Pomorskiego: Poddziatanie 1.1.1. Mikroprzedsiębiorstwa, $\mathrm{z}$ dotacjami dla mikroprzedsiębiorstw m.in. na udział w krajowych i międzynarodowych imprezach gospodarczych typu targi i wystawy w charakterze wystawcy.

\subsubsection{Instrumenty bezpośredniego wspierania przedsiębiorstw niezwiazane z funduszami strukturalnymi}

Do instrumentów bezpośredniego wspierania przedsiębiorstw niezwiązanych $\mathrm{z}$ funduszami strukturalnymi można zaliczyć cały pakiet rozporządzeń Rady Ministrów przyjętych tego samego dnia, co wskazuje na przemyślaną decyzję mającą na celu zapewnienie spójności i kompletności sytemu:

$\rightarrow$ pomoc de minimis dla przedsiębiorców na branżowe projekty promocyjne dotyczące eksportu, takie jak: pokazy, degustacje, wystawy, prezentacje, demonstracje, spotkania branżowe, szkolenia i warsztaty realizowane $\mathrm{w}$ kraju i za granica, udzielana na podstawie rozporządzenia Rady Ministrów z dnia 31 października 2007 r. w sprawie udzielania pomocy de minimis na realizację branżowych projektów promocyjnych w zakresie eksportu lub sprzedaży na Jednolitym Rynku Europejskim;

$\rightarrow$ pomoc de minimis dla MŚP na uzyskanie certyfikatów, świadectw i atestów wymaganych w obrocie wyrobami na rynkach zagranicznych, udzielana na podstawie rozporządzenia Rady Ministrów z dnia 31 października 2007 roku w sprawie udzielania pomocy de minimis na uzyskanie certyfikatu wyrobu wymaganego na rynkach zagranicznych;

$\rightarrow$ pomoc de minimis dla przedsiębiorców na przedsięwzięcia promocyjne, takie jak: seminaria, konferencje, zbiorowe pokazy oraz prezentacje, udzielana na podstawie rozporządzenia Rady Ministrów z dnia 31 października 2007 roku sprawie udzielania pomocy de minimis na realizację niektórych przedsięwzięć w zakresie promocji i wspierania eksportu lub sprzedaży na Jednolitym Rynku Europejskim;

$\rightarrow$ pomoc de minimis dla przedsiębiorców na wydawanie katalogów, informatorów (branżowych i regionalnych), folderów, obcojęzycznych wersji czasopism, publikacji książkowych oraz materialów promocyjnych i informacyjnych na nośnikach elektronicznych, promujących eksport lub sprzedaż na Jednolitym Rynku Europejskim, przy czym pomoc nie mogła być udzielana na publikację materiałów reklamowych indywidualnego przedsiębiorcy; pomoc udzielana jest na podstawie rozporządzenia Rady Ministrów z dnia 31 października 2007 roku w sprawie udzielenia pomocy de minimis na realizacje przedsięwzięć wydawniczych, promujących eksport lub sprzedaż na Jednolitym Rynku Europejskim.

\subsubsection{Instrumenty wspierajace innowacyjność przedsiębiorstw}

Ministerstwo Gospodarki w dokumencie zatytułowanym "Instrumenty umiędzynarodowienia działalności przedsiębiorców (Ministerstwo Gospodarki, 2010) do takich instrumentów zalicza również instrumenty wspierające innowacyjność przedsiębiorstw, tj. przede wszystkim proinnowacyjne działania Programu Operacyjnego Innowacyjna Gospodarka. Uzasadnione jest to stwierdzeniem, że „bez poprawy konkurencyjności i innowacyjności oferty produktowej polskich przedsiębiorstw trudno bedzie zwiększyć ich obecność na rynku globalnym" (Instrumenty, 2010, s. 8). Należy zauważyć, iż mimo że nie były to instrumenty proeksportowe, często kryteria wyboru projektów premiowały prowadzenie przez wnioskodawcę działalności za granicą lub sprzedaż produktów czy usług wytwarzanych w ramach projektu. 


\subsection{Instrumenty pośredniego wspierania przedsiębiorstw}

\subsubsection{Instytucje otoczenia biznesu $i$ sieci doradcze}

Tego typu podmioty oferują $\mathrm{z}$ reguły przedsiębiorcom pomoc $\mathrm{w}$ znalezieniu zagranicznych partnerów, przede wszystkim poprzez bazy ofert wspólpracy i udział w szkoleniach, dostęp do materiałów informacyjnych zamieszczanych w publikacjach i broszurach, a także na stronach internetowych. Dzięki dofinansowaniu przyznawanemu instytucjom otoczenia biznesu ze środków unijnych i z budżetu państwa tego typu usługi z reguły świadczone są bezpłatnie.

Instytucje otoczenia biznesu (IOB) oferują przedsiębiorcom także udział w wyjazdach na targi i misje gospodarcze oraz organizuja spotkania typu Business to Business (giełdy kooperacyjne i spotkania brokerskie). Jednak takie usługi $\mathrm{z}$ reguły wymagają od przedsiębiorcy pokrycia całości kosztów podróży, diet i zakwaterowania. Wartością dodaną takich wyjazdów organizowanych przez IOB jest przykładowo możliwość bezpłatnego wystawienia się na wspólnym stoisku, zamieszczenia profilu firmy w katalogu, obecność tłumacza, spotkania z wybranymi wcześniej potencjalnymi partnerami biznesowymi $\mathrm{w}$ ramach zorganizowanych spotkań B2B czy zapewniona infrastruktura do spotkań biznesowych. IOB organizuja polskim przedsiębiorcom także spotkania $\mathrm{z}$ zagranicznymi potencjalnymi partnerami biznesowymi na terenie Polski, najczęściej we współpracy z polskimi i zagranicznymi instytucjami odpowiedzialnymi za promocję eksportu i organizacje misji gospodarczych. W przypadku wyjazdów zagranicznych niekiedy pojawia się możliwość uzyskania dofinansowania $\mathrm{z}$ wymienionych $\mathrm{w}$ rozdziale 1 instrumentów bezpośredniego wspierania przedsiębiorstw, zdarza się też, że organizacje promujace eksport $\mathrm{w}$ danym kraju oferują przyjeżdżającym przedsiębiorcom częściowe pokrycie kosztów wyjazdu, bezpłatne wejściówki na imprezy czy bezpłatne katalogi.

Wśród instytucji otoczenia biznesu ze znaczącą ofertą takich usług można wymienić Krajową Izbę Gospodarczą, a z sieci doradczych Enterprise Europe Network, posiadającą ponad 600 partnerów w ponad 50 państwach. W Polsce działa 30 ośrod- ków sieci specjalizujących się w usługach z zakresu kojarzenia partnerów zagranicznych, organizacji misji gospodarczych i spotkań kooperacyjnych i brokerskich oraz międzynarodowego transferu technologii.

Należy także wspomnieć o możliwości korzystania przez polskie podmioty gospodarcze $\mathrm{z}$ możliwości oferowanych przez instytucje Unii Europejskiej, przykładowo w formie usług doradczych świadczonych europejskim MŚP przez EU SME Centre i SME IPR Helpdesk w Chinach oraz wyjazdów na misje gospodarcze do krajów pozaeuropejskich z Komisarzem ds. Przedsiębiorstw i Przemysłu w ramach inicjatywy „Missions for Growth”.

\subsubsection{Polskie placówki dyplomatyczne}

Polskie placówki dyplomatyczne oferują wsparcie dla polskich przedsiębiorców poprzez działające przy nich Wydziały Promocji Handlu i Inwestycji. WPHI wydają poradniki na temat rynku danego kraju i warunków prowadzenia na jego terenie działalności gospodarczej, zamieszczają na swoich stronach informacje o imprezach targowych oraz ważnych lokalnych instytucjach oraz organizują udział polskich przedsiębiorców $\mathrm{w}$ imprezach na swoim terenie.

\subsubsection{Centra Obstugi Inwestorów i Eksporterów (COIE)}

Centra Obsługi Inwestorów i Eksporterów (COIE) powstały w ramach Poddziałania 6.2.1 - Wsparcie dla sieci centrów obsługi inwestorów i eksporterów Programu Operacyjnego Innowacyjna Gospodarka, 2007-2013. Proces ich uruchamiania trwał dosyć długo, przede wszystkim z powodu przedłużających się negocjacji $\mathrm{z}$ urzędami marszałkowskim odpowiedzialnymi za ich prowadzenie, z których każdy miał własną wizję funkcjonowania takiej jednostki (PAG Uniconsult, 2011). Takie podejście może niestety oznaczać ryzyko braku spójności usług świadczonych przez poszczególne ośrodki.

Bezpłatne usługi proeksportowe oferowane przez COIE są zbliżone do tych oferowanych przez inne instytucje otoczenia biznesu, dodatkowo oferują one usługi informacyjne typu „probiz” dostępne dla inwestorów zagranicznych, zainteresowanych prowadzeniem działalności gospodarczej w Polsce. 


\subsubsection{Ustugi doradcze dla przedsiębiorców - Poddziatanie 6.5.1 PO IG}

W ramach projektu systemowego Ministerstwa Gospodarki pn: „Promocja Polskiej gospodarki na rynkach międzynarodowych" przewidziano m.in. przeprowadzenie badań wizerunkowych, na terenie krajów o istotnym znaczeniu eksportowym dla polskich przedsiębiorstw w celu opracowania kampanii informacyjno-promocyjnej, utworzenie portalu internetowego konsolidującego dotychczasowe źródła informacji nt. Polski oraz rynków zagranicznych i pełniącego funkcję platformy do nawiązywania kontaktów biznesowych z kontrahentami zagranicznymi i bazy umożliwiającej składanie ofert kupna i sprzedaży. Z kolei w celu pogłębienia wiedzy przedsiębiorców nt. specyfiki funkcjonowania rynków zagranicznych zaplanowano zakup opracowań, analiz, badań, opinii prawnych, ekspertyz rynkowych itp., które miały być udostępniane online wszystkim zainteresowanym podmiotom. Oprócz tego $\mathrm{w}$ ramach poddziałania zaplanowano realizację branżowych programów promocji, w formie m.in. „udziału przedsiębiorców w targach zagranicznych, misjach gospodarczych, konsultacjach, pokazach, spotkaniach branżowych, spotkaniach z kontrahentami, indywidualnych spotkaniach, doradztwie, szkoleniach, coachingu, opracowania i produkcji artykułów oraz materiałów promocyjnych" (http:// www.mg.gov.pl/Fundusze +UE/POIG/Dzialania/Dzialanie +651). Pomoc de minmis dla przedsiębiorców w tym zakresie była z kolei udzielana na podstawie rozporządzenia dotyczącego Poddziałania 6.5.2 PO IG.

\subsubsection{Portale informacyjne}

Wszystkie instytucje zaangażowane w system wspierania internacjonalizacji przedsiębiorstw prowadzą swoje strony internetowe, jednak większość zamieszczanych tam informacji dotyczy $z$ reguły jedynie ich własnych działań. $Z$ portali o większym zasięgu można wymienić dwa:

$\rightarrow$ wspólny portal Wydziałów Promocji

Handlu i Inwestycji (www.trade.gov.

$\mathrm{pl}$ ), zawierający m.in. opracowania własne Wydziałów Promocji Handlu i Inwestycji oraz materiały pochodzące z Ministerstwa Gospodarki i innych instytucji publicznych, a dotyczące rynków lokalnych, warunków prowadzenia działalności gospodarczej, imprez organizowanych przez WPHI itp.; $\rightarrow$ portal Promocji Eksportu (www.ekporter.pl); jednym z celów istnienia portalu jest integracja rozproszonych zasobów Internetu o tematyce gospodarczej, istotnych dla polskiego eksportera; zawiera on m.in. informacje gospodarcze o rynkach zagranicznych, dostęp do ofert eksportowych oraz informacje o instrumentach wspierania polskiego eksportu.

W ramach Poddziałania 6.5.1 PO IG zaplanowano konsolidację ww. portali. Niestety, pomimo tych planów, portale nadal funkcjonują oddzielnie.

\subsubsection{Inne instrumenty wsparcia}

Wśród innych instrumentów wsparcia można wymienić przykładowo:

$\rightarrow$ strategie Go China - inicjatywę Ministerstwa Gospodarki mającą na celu wypracowanie we współpracy z innymi agendami rządowymi wspólnej, spójnej strategii rozwoju współpracy z Chinami; częścią strategii jest portal internetowy (www.gochina.gov.pl), „mający na celu zebranie i uporządkowanie informacji dla przedsiębiorców na temat możliwości zaistnienia i współpracy na rynku chińskim; wielu przedsiębiorców wskazywało bowiem na to, że informacji o Chinach jest dużo, lecz jest ona rozproszona i trudna do zebrania w jednym miejscu" (www.gochina.gov.pl);

$\rightarrow$ strategię Go Africa, której celem jest zwiększenie polskich inwestycji w Afryce oraz zwiększenie wymiany handlowej; także w tym przypadku portal internetowy jest ważnym elementem strategii (www.goafrica.gov.pl);

$\rightarrow$ misje gospodarcze pod przewodnictwem wysokich ranga przedstawicieli kraju, np. wizyta Prezydenta Bronisława Komorowskiego w Chinach pod koniec 2011 r. czy wizyty polskich przedsiębiorców w wybranych krajach afrykańskich przy okazji wizyt w nich Premiera Donalda Tuska.

\subsection{Instrumenty finansowe}

Do instrumentów finansowych wspierających eksport można zaliczyć m.in.:

$\rightarrow$ Rządowy Program Wspierania Eksportu zarządzany przez Bank Gospodarstwa Krajowego, w ramach którego oferowane są instrumenty finansowania krótko-, średnio- i długoterminowego; 
$\rightarrow$ poręczenia i gwarancje Skarbu Państwa;

$\rightarrow$ ubezpieczenia finansowe i gwarancje ubezpieczeniowe oferowane przez Korporację Ubezpieczeń Kredytów Eksportowych (KUKE);

$\rightarrow$ rządowe kredyty eksportowe przeznaczone na finansowanie dostaw z Polski;

$\rightarrow$ program dopłat do oprocentowania kredytów eksportowych.

Wymienione powyżej instrumenty finansowe wspierające eksport ułatwiają polskim przedsiębiorcom prowadzenie transakcji handlowych z podmiotami zagranicznymi, m.in. dzięki bardziej korzystnym warunkom uzyskania kredytu, ułatwionemu dostępowi do poręczeń i gwarancji oraz udzielaniu nabywcom zagranicznych kredytów na zakup polskich towarów i usług, co sprzyja zwiększeniu wolumenu eksportu. Istotne znaczenie dla przedsiębiorców mają też instrumenty ubezpieczeniowe zmniejszające ryzyko prowadzenia międzynarodowej wymiany handlowej.

\subsection{Wspieranie internacjonalizacji przedsiębiorstw $w$ perspektywie finansowej 2014-2020}

W obecnej perspektywie finansowej 2014-2020 także przewidziano instrumenty wspierające internacjonalizację polskich przedsiębiorstw. Działania te będą realizowane w ramach Celu Tematycznego 3: Wzmacnianie konkurencyjności małych i średnich przedsiębiorstw, sektora rolnego oraz sektora rybołówstwa i akwakultury, Priorytet Inwestycyjny (PI) 3.2: Opracowywanie i wdrażanie nowych modeli biznesowych dla MŚP, w szczególności w celu internacjonalizacji. PI 3.2. realizuje Cel Szczegółowy 5: Wzrost umiędzynarodowienia działalności przedsiębiorstw, dla którego wskaźnikiem rezultatu jest „Udział eksportu wyrobów wysokiej techniki w eksporcie ogółem”. Instrumenty wspierające internacjonalizację wdrażane będą w ramach:

$\rightarrow$ Programu Operacyjnego Inteligentny Rozwój (PO IR): wsparcie kierowane do innowacyjnych przedsiębiorstw, w szczególności w zakresie projektów przyczyniających się do nawiązania przez przedsiębiorstwa kontaktów $\mathrm{z}$ zagranicznymi kontrahentami i inwestorami, w tym także za pośrednictwem instytucji otoczenia biznesu; przewidziano także wsparcie realizacji projektów systemowych w zakresie udostępniania wiedzy na temat umiędzynarodowienia działalności MŚP oraz promowania takiej działalności; w PO IR dla PI 3.2. przewidziano zarówno dotacje, jak i instrumenty finansowe;

$\rightarrow$ Programu Operacyjnego Polska Wschodnia $(P O P W)$ : wspieranie aktywności międzynarodowej przedsiębiorstw poprzez kompleksowe indywidualne doradztwo oraz promocję proeksportowa, ze szczególnym uwzględnieniem klastrów prowadzących działalność $\mathrm{B}+\mathrm{R}+\mathrm{I}$;

$\rightarrow$ Regionalnych Programów Operacyjnych: projekty przedsiębiorstw mające na celu wzrost eksportu i zdobywanie nowych rynków zbytu, przy czym wsparcie adresowane jest także do firm nieprowadzących działalności $\mathrm{B}+\mathrm{R}+\mathrm{I}$; ponadto przewidziano wsparcie na działania promocyjne, stymulujące internacjonalizację gospodarki regionów.

Obecnie, ze względu na nadal trwające prace nad przygotowaniem dokumentacji programowej brakuje jeszcze szczegółowych informacji na temat planowanych konkretnych instrumentów wsparcia, co nie pozwala na ich ocenę w kontekście doświadczeń zgromadzonych w perspektywie finansowej 2007-2013.

\section{Wnioski}

Autorka starała się przedstawić pełny obraz systemu wspierania internacjonalizacji przedsiębiorstw w perspektywie budżetowej 2007-2013, jednakże ze względu na znaczną jego złożoność nie można wykluczyć, że obejmuje on także inne instrumenty niewymienione $\mathrm{w}$ niniejszym opracowaniu.

Wydaje się, że istnieje spójność systemu w zakresie rodzajów oferowanego wsparcia: $\mathrm{z}$ jednej strony oferowane są instrumenty wsparcia bezpośredniego w postaci dofinansowania, z drugiej zaś - szeroki wachlarz usług, w których przedsiębiorca nie otrzymuje środków finansowych tylko usługi asysty, doradztwa, informacji czy szkoleń. Ponadto oferowane jest wsparcie w postaci instrumentów finansowych ułatwiających prowadzenie działalności eksportowej i obniżających jej ryzyko. Można więc stwierdzić, że system jest spójny w następujących aspektach:

$\rightarrow$ system wdrażany w latach 2007-2013 oferował pełen zakres instrumentów 
istotnych dla procesu internacjonalizacji przedsiębiorstw, na różnych etapach tej działalności, tj. od podjęcia decyzji o internacjonalizacji (głównie przy udziale instrumentów wsparcia w postaci doradztwa, informacji i szkoleń), poprzez działania inicjujące proces internacjonalizacji (np. dzięki dotacjom w ramach Paszportu do eksportu czy dofinansowaniu udziału w targach i misjach gospodarczych) aż do instrumentów (głównie finansowych i zmniejszających ryzyko) oferowanych przedsiebiorcom faktycznie prowadzącym działalność eksportową;

$\rightarrow$ system obejmował instrumenty adresowane zarówno do przedsiębiorców indywidualnych, jak i grup przedsiębiorców;

$\rightarrow$ system dopuszczal korzystanie przez beneficjentów $\mathrm{z}$ różnych instrumentów wsparcia, przy zastosowaniu przepisów dotyczących pomocy de minimis (tj. nie więcej niż 200000 EUR dla jednego przedsiębiorcy w ciągu 3 lat) i kumulacji pomocy publicznej, a także przy przestrzeganiu zasady komplementarności i linii demarkacyjnej między programami.

Jednakże w związku z dokonaną powyżej analizą oraz obserwacją praktyki życia gospodarczego wydaje się, że obecny system, w który zaangażowanych jest wiele instytucji często dublujących usługi, oferujących znaczną liczbę instrumentów wsparcia, prowadzących oddzielne portale informacyjne itd. należy ocenić jako w wysokim stopniu rozproszony. Ponadto nasuwają się następujące wnioski:

$\rightarrow$ Dla poszczególnych działań w dokumentach programów operacyjnych przewidziano komplementarność z innymi działaniami i priorytetami, jednakże trudno jest stwierdzić czy jest ona faktycznie zachowywana. W przytoczonej już w niniejszym artykule ewaluacji (PAG Uniconsult, 2011), wskazano na problemy z komplementarnością i tzw. linią demarkacyjną, czyli przyporządkowaniem określonych typów projektów do danych programów, w szczególności pomiędzy Programem Operacyjnym Innowacyjna Gospodarka a Regionalnymi Programami Operacyjnymi, a nawet $w$ ramach samego PO IG: „Przedsiębiorcy chcący uczestniczyć w wyjazdach na targi czy misje, mogli też korzystać ze wsparcia w ramach dzia- łania 6.1 i poddziałania 6.5.2, a także wsparcie w ramach regionalnych programów operacyjnych. Oczywiście działania te miały nieco inna naturę, ale z punktu widzenia przedsiębiorców ich kształt mógł się wydawać zbliżony" (PAG Uniconsult, 2011, s. 50). W rezultacie działania mogły się dublować, a przedsiębiorcy nie byli w stanie zidentyfikować różnic pomiędzy instrumentami wsparcia.

$\rightarrow \mathrm{W}$ tejże ewaluacji (PAG Uniconsult, 2011, s. 148) postawiono również pytanie o to, ,czy z punktu widzenia beneficjentów działania 6.1, klarowny był inny charakter zapewnianego w jego ramach wsparcia, w porównaniu ze wsparciem zapewnianym $w$ ramach regionalnych programów operacyjnych i polegającym na wspieraniu działań obejmujacych udział przedsiębiorców w targach, wystawach, misjach gospodarczych?" Zgodnie z udzielonymi odpowiedziami, ponad $1 / 3$ beneficjentów działania 6.1 nie dostrzegało większych różnic pomiędzy nimi, $1 / 3$ je dostrzegała, a również $1 / 3$ nie miała zdania. Potwierdza to więc, że beneficjenci nie rozumieją powodów różnicowania instrumentów, co stawia pytanie o zasadność takich działań.

$\rightarrow$ Pojawia się sytuacja dublowania usług, np. świadczonych przez COIE i istniejące wcześniej organizacje. Można więc rozważać czy w takich sytuacjach uzasadnione jest tworzenie zupełnie nowych jednostek organizacyjnych, czy może lepszym rozwiązaniem byłoby wprowadzenie ewentualnych modyfikacji już istniejących struktur organizacyjnych, a następnie ich dofinansowanie $\mathrm{z}$ przeznaczeniem na świadczenie nowych usług albo nawet usług $\mathrm{w}$ dawnej postaci, ale dostępnych dla większej grupy zainteresowanych podmiotów.

$\rightarrow$ W praktyce występuje zjawisko konkurowania instytucji o tego samego beneficjenta. Można tu przywołać przykład programu Go global.pl realizowanego przez Narodowe Centrum Badań i Rozwoju i projektu „Polski Most Krzemowy" realizowanego przez Polską Agencję Rozwoju Przedsiębiorczości i Ministerstwo Gospodarki w ramach Programu Operacyjnego Innowacyjna Gospodarka. Z obydwu ww. schematów wsparcia można uzyskać dofinansowanie na ekspansję firmy w Dolinie Krzemowej. Należy więc rozważyć czy 
realizowanie przez różne instytucje projektów o zbliżonym charakterze, a co więcej dotyczących tych samych rynków jest rzeczywiście zasadne z punktu widzenia efektywności systemu i beneficjentów pomocy.

$\rightarrow \mathrm{W}$ badaniu Komisji Europejskiej wskazywano na niski poziom wiedzy o publicznych możliwościach wsparcia, można więc założyć, że dla firm z sektora MŚP znaczna ilość rozproszonych informacji może być trudna do zgromadzenia i przetworzenia, a $\mathrm{w}$ rezultacie zniechęcać do korzystania ze wsparcia. Zdobywanie informacji o możliwościach uzyskania wsparcia, a następnie korzystanie $\mathrm{z}$ niego stanowi więc obciążenie administracyjne, co jest szczególnie istotne $\mathrm{w}$ przypadku firm $\mathrm{z}$ sektora MŚP. Przykładowo można wspomnieć o konieczności kilkukrotnego opracowywania profilu firm w celu zamieszczenia go w różnych bazach.

$\rightarrow$ Należy zwrócić uwagę na jakość udostępnianych informacji, w szczególności na stronach internetowych instytucji: informują one $\mathrm{z}$ reguły jedynie o własnych działaniach, a prezentowane informacje często są zdezaktualizowane, przez co mogą wprowadzać w błąd.

$\rightarrow$ Ostatnia kwestia, wykraczająca już poza kwestię spójności systemu wsparcia internacjonalizacji, to pytanie czy system wsparcia w dotychczasowym kształcie, przewidujący znaczącą ilość instrumentów wsparcia pośredniego (np. doradztwo, szkolenia) odpowiada na potrzeby przedsiębiorców, którzy jak już wspomniano najbardziej cenią sobie bezpośrednie wsparcie finansowe?

W perspektywie budżetowej 2014-2020 również przywiązuje się dużą wagę do zagadnienia internacjonalizacji, szczególnie w odniesieniu do MŚP. Zdefiniowane powyżej zagadnienia problemowe i proponowane rozwiązania, określone na podstawie analizy systemu wspierania internacjonalizacji przedsiębiorstw obowiązującego w latach 2007-2013, mogą więc posłużyć jako punkt wyjścia do dyskusji nad szczegółowym kształtem systemu w nadchodzącym okresie. Wydaje się, że rządzący powinni w szczególności skupić się na zmniejszaniu rozproszenia informacji oraz na lepszej koordynacji działań zaangażowanych instytucji. Należy w końcu wdrożyć stronę internetową udostępniającą $\mathrm{w}$ jednym miejscu wszystkie informacje istotne dla międzynarodowej działalności przedsiębiorców. Dla spójności systemu wspierania internacjonalizacji przedsiębiorstw niezwykle istotna jest także rzeczywista współpraca zaangażowanych instytucji, a nie ich konkurowanie, a w szczególności aktywna postawa placówek dyplomatycznych, jako instytucji będących najbliżej potencjalnych rynków zbytu. Dyskusyjne jest także wprowadzanie do systemu wsparcia instrumentów bardzo podobnych, np. takich jak wsparcie udziału w targach i misjach handlowych w ramach Paszportu do eksportu, Poddziałania 6.5.2 PO IG oraz instrumentów proeksportowych w Regionalnych Programach Operacyjnych.

\section{Przypis}

1 Więcej informacji na temat specyfiki MŚP w kontekście internacjonalizacji znajduje się w p. I.

\section{Bibliografia}

EIM Business \& Policy Research na zlecenie Komisji Europejskiej. (2010). Internationalisation of European SME, Final Report. Brussels.

Gorynia, M. (2002). Internacjonalizacja gospodarki a polityka gospodarcza w warunkach integracji i globalizacji. W: J. Rymarczyk i W. Michalczyk (red.), Internacjonalizacja i globalizacja przedsiębiorstwa i gospodarki, (t. I s. 237-243). Wrocław: Wydawnictwo Akademii Ekonomicznej im. Oskara Langego.

Koncepcja horyzontalnej polityki przemystowej w Polsce. Projekt z dnia 19 lutego 2007 r., przyjęty przez Radę Ministrów 30 lipca 2007 r.

Korsakienè, R. i Tvaronavičienè, M. (2012). The internationalization of SMEs: an integrative approach. Journal of Business Economics and Management, 13(2), 294-307.

Ministerstwo Gospodarki, Departament Instrumentów Wsparcia. (2010). Instrumenty umiędzynarodowienia dziatalności przedsiębiorców. Warszawa.

PAG Uniconsult na zlecenie Ministerstwa Rozwoju Regionalnego. (2011). Ocena stanu realizacji 3, 4, 5 i 6 priorytetu PO IG w połowie okresu programowania. Raport końcowy. Warszawa.

Policy \&Action Group Uniconsult Sp. z o.o., na zlecenie Polskiej Agencji Rozwoju Przedsiębiorczości. (2009). Plany i potrzeby przedsiębiorców sektora MŚP w zakresie rozwoju eksportu i powiązań z zagranicznymi rynkami i partnerami handlowymi, w kontekście uruchomienia działania 6.1 PO IG „Paszport do eksportu”, Raport końcowy. Warszawa Portal Promocji Eksportu Ministerstwa Gospodarki, www.eksporter.gov.pl. 
Program Operacyjny Innowacyjna Gospodarka, 2007-2013. (2013). Wersja ujednolicona.

Program Operacyjny Inteligentny Rozwój, 2014-2020. Projekt ze stycznia 2014 r.

Rymarczyk, J. (2004). Internacjonalizacja i globalizacja przedsiębiorstwa. Warszawa: Polskie Wydawnictwo Ekonomiczne.

Serwis informacyjny Wydziałów Promocji Handlu i Inwestycji Ambasad i Konsulatów RP (WPHI), www.trade.gov.pl.

Sporek, T. (2000). Internacjonalizacja przedsiębiorstwa, teoria i współczesność. W: T. Sporek (red.), Procesy internacjonalizacji we wspótczesnej gospodarce światowej (s. 51-66). Katowice: Akademia Ekonomiczna im. Karola Adamieckiego.

Strona internetowa Ministerstwa Gospodarki, http://www.mg.gov.pl/Fundusze + UE/POIG/Dzialania/Dzialanie +651 .
Szczegótowy opis priorytetów Programu Operacyjnego Innowacyjna Gospodarka, 2007-2013. Wersja z 22 października 2013 r.

Szczegótowy Opis Priorytetów Regionalnego Programu Operacyjnego dla Województwa Dolnoślaskiego na lata 2007-2013 (Uszczegótowienie RPO WD). Wersja z 2012 r.

Szczegótowy Opis Priorytetów Regionalnego Programu Operacyjnego Województwa Mazowieckiego na lata 2007-2013. Wersja z 27 maja 2014 r.

Umowa Partnerstwa, w wersji zaakceptowanej 23 maja 2014 r. przez Komisję Europejską.

Uszczegótowienie Regionalnego Programu Operacyjnego dla Województwa Pomorskiego na lata 2007-2013. Wersja z dnia 10 września 2009 r.

www.goafrica.gov.pl.

www.gochina.gov.pl. 